\title{
Process Reengineering and Innovation of Remaking Soapsuds
}

\author{
Andreja Verbič 1 , Tomaž Kern², Drago Vuk² \\ 1Trnovlje 18, 4207 Cerklje, Slovenija, Marko.Verbic1@t-2.net \\ 2University of Maribor, Faculty of Organizational Sciences, Kidričeva cesta 55a, 4000 Kranj, \\ Tomaz.Kern@fov.uni-mb.si, Drago.Vuk@fov.uni-mb.si
}

\begin{abstract}
This article uses a business process renovation method to address an environmental protection problem. The presented case, studied in factories which remake crude vegetable oil (soapsuds remake), focuses on reengineering one of the business processes which is classified as an obligatory process. This process has to be performed to comply with the requirements of the existing ecology legislation. Therefore, it is reasonable to take a radical approach - business process reengineering. Soapsuds with oil remnants are a secondary product in the vegetable oil refining process. According to the legislation, secondary products as waste are not acceptable for the environment. Soapsuds remake as it is currently carried out produces technical fatty acids and, as a side product, calcium sulphate. Calcium sulphate is listed as special waste; therefore it must be deposited in a special waste landfill site. In the course of searching for a solution to this ecological problem, a new idea came up, namely that soapsuds are taken to the biogas plant. At the biogas plant, they can be decomposed into biogas, which is then used to generate electric energy, for heating or to supplement municipal gas. Thus, the reengineering of the process is upgraded into process innovation and environmental innovation. Using data obtained from the available literature, we managed to prove that process reengineering, which is simultaneously process innovation and ecological innovation, can be applied in practice. Side products resulting from the anaerobic digestion of soapsuds in the biogas plant comply better with the requirements of the Slovenian ecological legislation than those occurring in the process used up to now.
\end{abstract}

Key words: business process reengineering, process innovation, soapsuds remake, biogas plant, ecology

\section{Introduction}

The constant new demands of the market and fast technological development require that organisations increase value for the customer, cut costs and stay competitive. In addition, they have to comply with legislative requirements, in particular with the ecology legislation, which is becoming more and more stringent.

We are living in the age of globalization; therefore companies need to adjust to the new conditions. The efficiency of an organization is based on timely and efficient adjustment to market conditions, new product conditions, economic factors and the social environment. In the past, the main form of an organization was its structure, something which has not changed significantly over time. However, today it is a key process which is constantly changing. Here we have information about what goes on within a company (Vila, 2009).

Too wide a gap between the structure and processes results in an inefficient business system. The productivity and commercial success of an organization depend on its harmonization of key production factors: human resources, technology and organization of work.
Therefore, today major emphasis is placed on business process reengineering, which can gradually, continually or radically transform business processes.

Companies also endeavour to achieve a competitive advantage by investing into equipment, technology and development, with varying degrees of success. The reasons for technological changes in companies are usually a combination of the following factors (Frankel, 1990):

- market pressure to improve products and services;

- competitive pressure and competition on the market;

- the company's endeavours to increase production;

- scientific developments;

- moral factors, e.g. national pride, and

- coincidences (innovations and inventions, etc.)

The fact that society, social groups and individuals have to continually prove themselves by coming up with innovations and new products, which is not only very interesting, but also commercially viable on the commodities market. Therefore, in order to find a good idea, we need not only theoretical knowledge, but also experience and practice.

Ecology has played an increasingly important role in recent times. With regard to protect environment due to global environmental changes and, consequently, the ever stricter ecology legislation, we can conclude that today's market 
Organizacija, Volume 42

Research papers

Number 5, September-October 2009

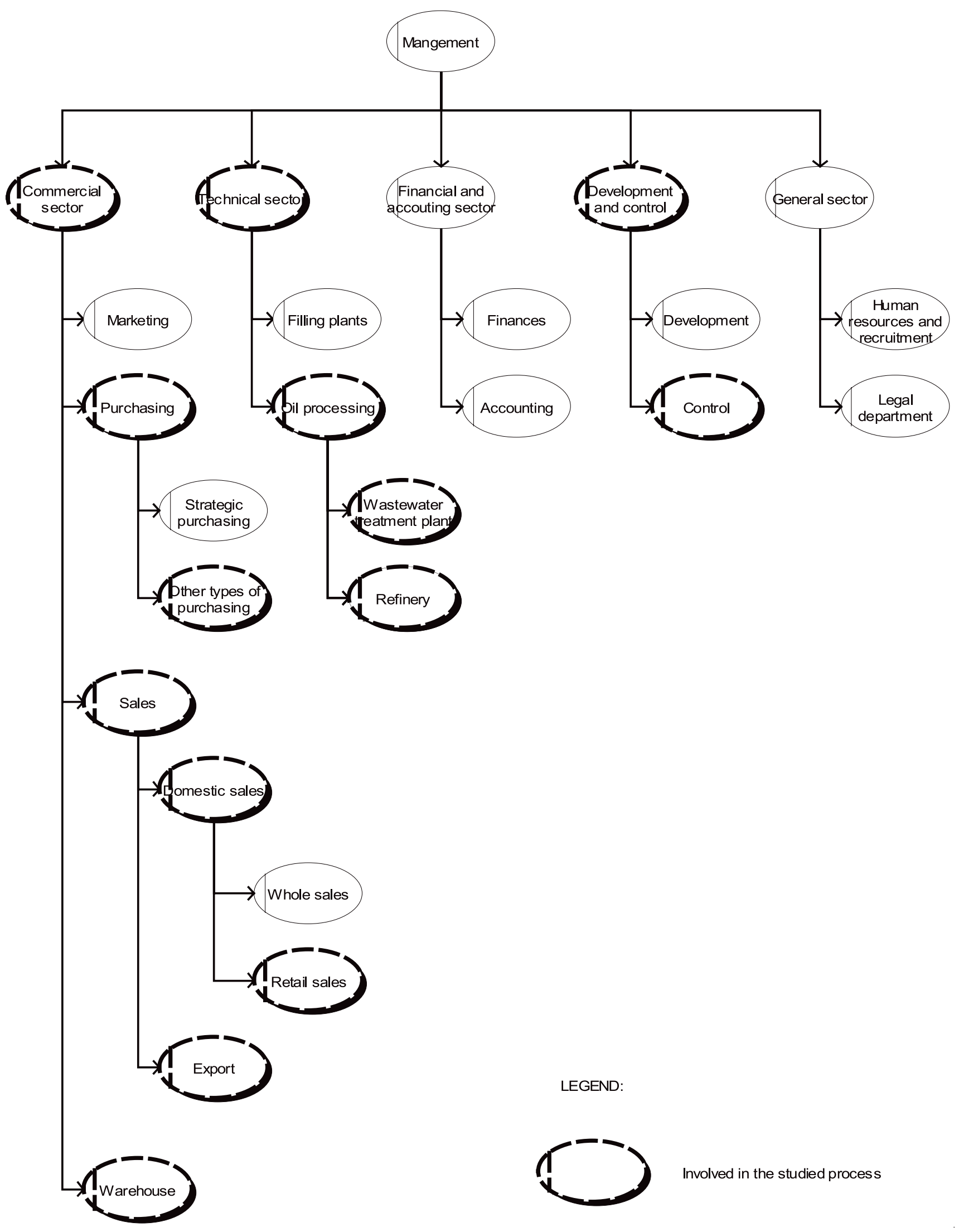

Figure 1: Organizational structure - model (Verbič, 2008).

166 
economy has started to transform into an ecological market economy.

The sustainable development policy has changed the basic marketing approach, making environmental protection an important part of a marketing strategy (Vuk and Senegačnik, 2003). Ecology is thus an important marketing opportunity, an opportunity to ensure competitiveness, as well as a significant entrepreneurial challenge.

The theoretical findings mentioned in this article will be used with reengineering and innovating the obligatory process (soapsuds remake). Soapsuds are side product in vegetable oil processing (mostly sunflowerseed oil, rapeseed oil, soybean oil and various mixtures of these oils) so as to obtain refined vegetable oils or oils for technical purposes. Soapsuds are a waste material which is not acceptable for the environment, therefore it needs to be remake so as to comply with the requirements of the ecological legislation.

Since a company has to perform this process, its aim is to do so as cheaply as possible or perform it in a way which proves the most beneficial in terms of added value for the business system.

Business process reengineering provides such a possibility (Kern 2003, Kern 2008, IDS Scheer, 2004). In addition, there is the idea of transporting soapsuds to the biogas plant. The company would collect a sufficient amount of soapsuds and then dispatch them to the biogas plant. This would significantly shorten and simplify the process for the company.

For remaking soapsuds in the biogas plant, the effect of the anaerobic digestion of soapsuds on the operation of the biogas plant is important. Based on the information in the available literature, we will research the effect of soapsuds on the operation of the biogas plant and prove that products resulting from this anaerobic digestion are more acceptable for the environment.

\section{Presentation of the current situation}

The obligatory process of soapsuds remake takes place in companies which process vegetable oils into refined vegetable oils or oils for technical purposes. Mostly, these are sunflowerseed oil, rapeseed oil, soybean oil and mixtures of these oils. Soapsuds are a waste material which is not acceptable for the environment, therefore it needs to be remade into products which present less of an environmental pollution. Therefore, the soapsuds remake (as a secondary product) is listed as an obligatory process.

\subsection{Organizational and human resources structure of the business system}

In our research we studied several companies which remake soapsuds ${ }^{1}$. Companies whose main activity is vegetable oil processing are organized as limited liability companies (d.o.o.) or public limited companies (d.d.). In most cases, the organizational structure is hierarchical. This organizational structure within a company is presented in the organizational structure model given below (Figure 1).

As a rule, these companies employ a large number of people with less than secondary school/high school education and only a small percentage of people with university education (estimated 10\%).

\subsection{Business system processes}

In business systems whose main activity is processing vegetable oils (but also in other business systems) several processes take place: management processes (with sub-processes: training, strategy, human resources recruitment, legal processes); commercial processes (with sub-processes: sales, purchasing, marketing, storage, transport); research and control; processing of crude oil into refined oil or oil for technical purposes (with sub-processes: filling plants, soapsuds remake, wastewater treatment, maintenance). The identification process - processing of crude vegetable oil - is at the same time a basic transformational process and a beneficial process which results in output, i.e. it brings added value to the business system (Verbič and Kern, 2008).

The processing of crude vegetable oil is continuous. One of the phases is neutralization of the oil, wherein by means of phosphoric $(\mathrm{V})$ acid, $\mathrm{H}_{3} \mathrm{PO}_{4}$, non-hydratable phosphatides are removed (degumming of crude oil). With sodium hydroxide, $\mathrm{NaOH}$, saturated and unsaturated free fatty acids are removed (neutralization of crude oil). These processes produce soapsuds (aqueous soap solution) as a secondary product. They are separated from the oil in a separation process based on various densities (oils are lighter than aqueous soap solutions). This process is necessary because free fatty acids decompose within oil and contribute to rancidity which causes rapid deterioration of the oil.

\subsection{Detailed description of the researched process}

Soapsuds remake (soap splitting), as presented in this article, is considered an obligatory process. It must be performed so as to comply with the ecology legislation.

Soap splitting is either a continuous process or a process which takes place in batches (batch soap splitting). In Slovenia, batch soap splitting is more common, therefore it is this process that will be described here (Verbič, 2008, Verbič and Kern, 2008).

An aqueous soap solution is gathered in a special batch, in a room which is physically separated from other parts of the refinery (one or more batchs). After the batch has been filled, the worker in charge starts with the process. The reaction takes place at a temperature of $80-90{ }^{0} \mathrm{C}$. During intensive mixing, which takes place for 3 hours, concentrated sulphuric acid $\mathrm{H}_{2} \mathrm{SO}_{4}$ is added to the solution. This reaction reproduces technical fatty acids which separate from the solution (they are lighter than the aqueous solution). The techni-

${ }^{1}$ The data are generalized to keep business secrets. The problem in the article is studied without finding out business secrets. 
CURRENT PROCESS - MODEL (AS-IS)

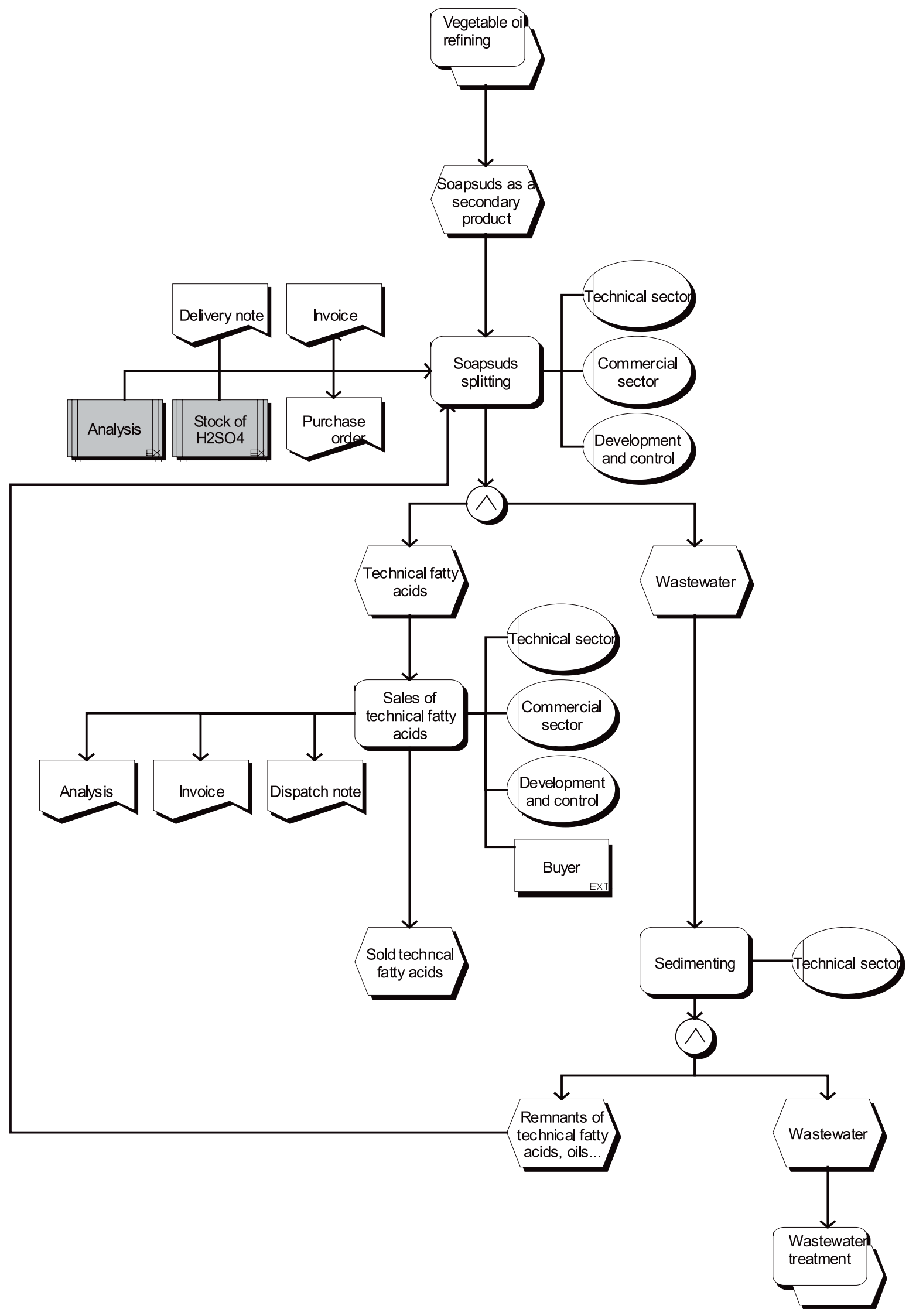

Figure 2: Soapsuds remake - model (Verbič, 2008). 

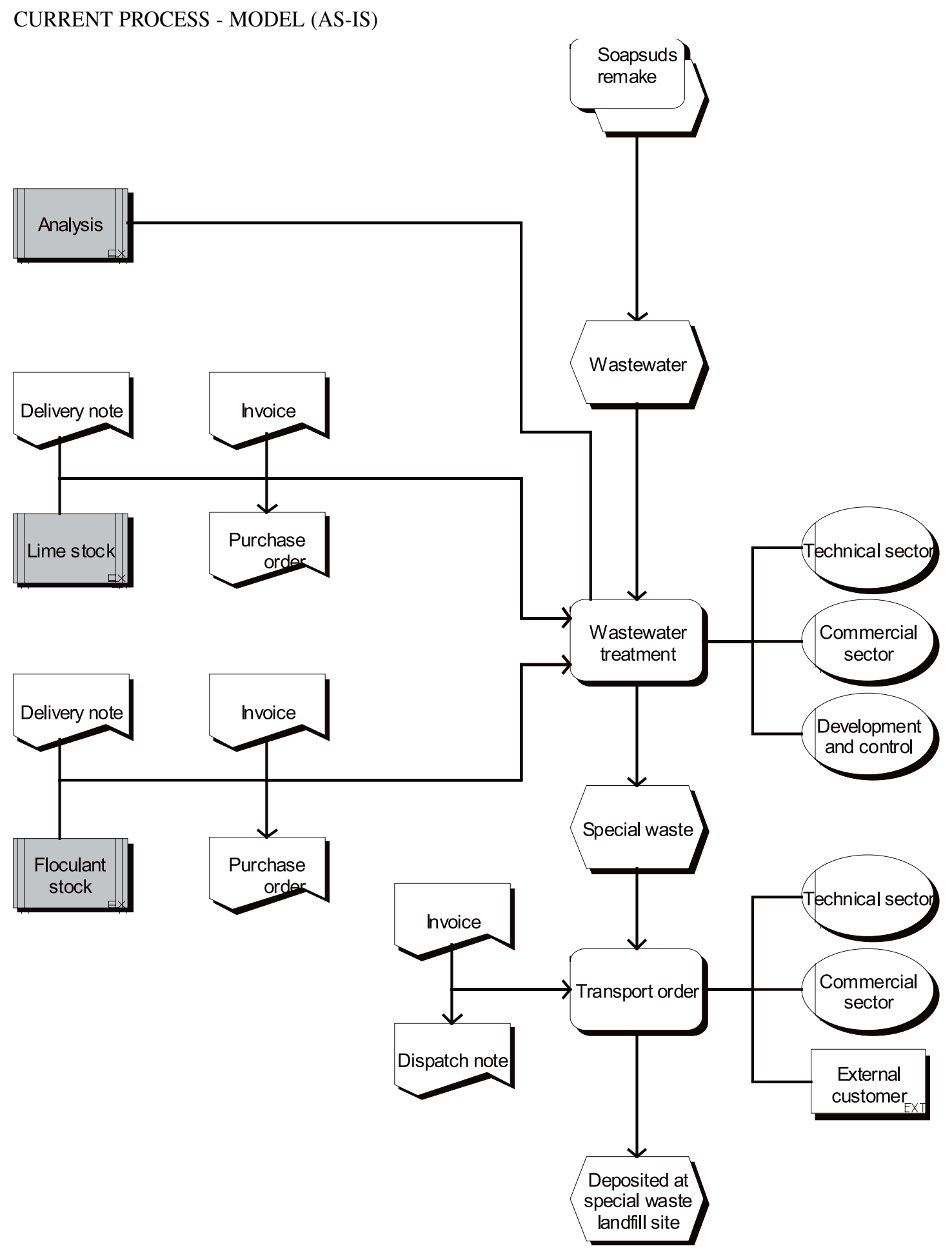

Figure 3: Soapsuds remake - model (wastewater treatment) (Verbič, 2008).

cal fatty acids are then filtered and washed with water (Swern, 1964). The laboratory takes a sample to test for any remnants of sulphuric acid and water in the technical fatty acids. The results of the laboratory analyses are recorded in the electronic analysis logbook. The refinery line manager and the worker in the room where the batch soap splitting takes place, have access to the electronic analysis logbook. If the results of the analysis comply with the production specifications, the worker pumps the technical fatty acids into a reservoir; if they do not, the process of washing, sedimenting and sampling is repeated. The refinery line manager makes an entry in the refinery work logbook (and in the electronic logbook) recording the amount of sulphuric acid used, which is kept in reservoirs. 
The refinery line manager also monitors the stock of sulphuric acid (he/she records this data electronically and submits a purchase order via intranet to the Purchasing Department). The purchasing clerk completes the purchase. The refinery line manager takes delivery of the package of sulphuric acid, records the quantity in the electronic logbook, signs the delivery note and sends it to the Purchasing Department, wherein the procedure (after receipt of the invoice) is completed.

The refinery line manager also monitors the quantity of fatty acids in the reservoirs. When the amount is sufficient, the refinery line manager orders the sale of the technical fatty acids (for the cosmetic industry) to the Sales department clerk. The Sales department clerk completes the sales procedure. After a warehouse worker has pumped the technical fatty acids into a cistern vehicle, the head of the warehouse fills out the dispatch note (prepared by the Sales department clerk) with information about the quantity of technical fatty acids to be shipped and sends the dispatch note to the Sales department clerk. The laboratory clerk receives a written document with an analysis signed by the head of the laboratory and, together with the dispatch note and the invoice, submits them as accompanying documents (Verbič, 2008, Verbič and Kern, 2008).

The second part involves wastewater. The resulting wastewater - the aqueous solution of sodium sulphate $\left(\mathrm{Na}_{2} \mathrm{SO}_{4}\right)$ and the remnants of sulphuric acid, soap, phosphates and neutral oil - the fatty phase, is piped into sedimentation chambers (where the remnants of the fatty phase are separated from the wastewater). From there, the fatty phase continues to the batch soap splitting, while the wastewater continues to the waste water treatment plant (Swern, 1964). Usually, companies have their own waste water treatment plants.

The aforementioned wastewater is collected in the equalisation pool of the waste water treatment plant. Sulphates are removed from the wastewater using lime. Solid calcium sulphate, $\mathrm{CaSO}_{4}$, is precipitated (with the remnants of the substances listed above). It is removed from the wastewater by the addition of a floculant and transported to a special waste landfill site, as this waste still a special waste (Figure 6).

The procedure used to purchase lime and floculant is identical to the purchase of sulphuric acid, except that it is done by the line manager of the waste water treatment plants. The process of dispatching the calcium sulphate is completed by the Sales department clerk, who prepares the dispatch note and receives the invoice for transport and deposition (Verbič, 2008, Verbič and Kern, 2008).

Technical fatty acids are a product which brings added value, but also incurs costs during production: the cost of the sulphuric acid and lime, work costs, costs of transporting and depositing the calcium sulphate in the special waste landfill site, energy costs, investment into equipment, tax for pollution of the environment. The process of soapsuds remake is presented in the models given below (Figures 2 and 3).

\subsection{Description of schedule for individual functions}

The schedule of the process is given in the following table.

Table 1: The schedule of the process (Verbič, 2008).

\begin{tabular}{|l|l|l|l|l|}
\hline & AWAITING EXECUTION & $\begin{array}{l}\text { PREPARATION } \\
\text { FOR EXECUTION }\end{array}$ & EXECUTION & FINALISATION \\
\hline SOAP SPLITING & $\begin{array}{l}\text { cca } 8 \text { hours until the batch is } \\
\text { full }\end{array}$ & 30 minutes & 4 hours* & 5 minutes \\
\hline $\begin{array}{l}\text { LABORATORY - ANALYSIS OF } \\
\text { TFA }\end{array}$ & 10 minutes & 7 minutes & 10 minutes & 5 minutes \\
\hline $\begin{array}{l}\text { REPUMPING TFA INTO THE } \\
\text { RESERVOIR }\end{array}$ & 5 minutes & 2 minutes & 15 minutes & 5 minutes \\
\hline $\begin{array}{l}\text { REPUMPING WATER INTO THE } \\
\text { CLEANING PLANT }\end{array}$ & 5 minutes & 5 minutes & 15 minutes & 5 minutes \\
\hline $\begin{array}{l}\text { PURCHASE OF SULPHURIC } \\
\text { ACID, LIME AND FLOCULANT }\end{array}$ & 5 minutes & 5 minutes & 10 minutes & 5 minutes \\
\hline DELIVERY OF CHEMICALS & 5 minutes & 3 minutes & 30 minutes & 10 minutes \\
\hline $\begin{array}{l}\text { TFA SALES PROCEDURE } \\
\text { fFALYSIS OF TFA FROM THE } \\
\text { COLLECTION RESERVOIR }\end{array}$ & 10 minutes & 30 minutes & 30 minutes & 10 minutes \\
\hline $\begin{array}{l}\text { PUMPING TFA INTO A CISTERN } \\
\text { VEHICLE FOR TRANSPORT }\end{array}$ & 10 minutes & 7 minutes & 10 minutes & 10 minutes \\
\hline $\begin{array}{l}\text { FINAL PROCEDURE IN SALES } \\
\text { DEPARTMENT }\end{array}$ & 5 minutes & 7 minutes & 25 minutes & 7 minutes \\
\hline $\begin{array}{l}\text { WASTEWATER TREATMENT } \\
\text { TOTAL }\end{array}$ & 55 minutes & 5 minutes & 10 minutes & 10 minutes \\
\hline
\end{tabular}

NOTES: * 0.5 hour for heating, 3 hours for batch soap splitting and 0.5 hour for washing 
The times for the individual process stages are long, but they cannot be significantly shortened with the same chemical procedures (Verbič and Kern, 2008).

\section{The analysis}

\subsection{Analysis of the process structure}

The process itself is rather complicated, as it includes 19 workers (from the purchasing department, sales department, refinery, warehouse, cleaning plant and laboratory). As regards the number of people involved in the process, we took account of the fact that the batch soap splitting takes place during three shifts, whereas wastewater treatment during two shifts. The procedure is complicated and is performed in three organizational units and at three levels within the organizational units (Figure 1). The process itself should be simplified, i.e. it should involve fewer workers who would perform a greater number of consecutive tasks. There is no technical support for monitoring the quantity of chemicals and technical fatty acids in reservoirs. If this was available, the waiting and preparation time would be shortened however we cannot significantly shorten the technological time with the same kind of chemical procedures (Verbič and Kern, 2008).

\subsection{Time analysis of the process}

In terms of time, it takes around 16 hours to perform this process. It is impossible to significantly shorten the technological time for performing the process (which is the most time consuming) with the same kind of chemical procedures.

\subsection{Analysis of influential factors}

With regard to the ecological legislation currently applicable both in Slovenia and in the European Union, and the ecological policies of Slovenia and the European Union, both of which support sustainable development, it seems clear that environmental protection has become more of an important issue. We can expect that tax for pollution of the environment will increase, making it necessary to find solutions which will be financially more beneficial for the business system and will, at the same time, comply with the ever more stringent ecological legislation.

\subsection{Comparative analysis}

Business systems whose main activity is vegetable oil processing (through alkaline refining) are dealing with this problem in a similar manner. The difference lies in the fact that some of them opt for batch soap splitting, while others apply a continuous soap splitting, while wastewater is treated either in their own wastewater treatment plants or they pay for it to be treated in communal wastewater treatment plants.

\section{Proposal for reengineering and innovation of the process}

\subsection{The process after reengineering and innovation}

Since a company has to perform this process, its aim is to do as cheaply as possible or perform it in a way which proves the most beneficial in terms of added value to the business system.

Business process reengineering offers this possibility. While searching for a solution, it was proposed that soapsuds should no longer be remade, but taken to a biogas plant instead (Figure 7). At the biogas plant they can be decomposed into biogas, which is then used to generate electric energy, for heating or to supplement municipal gas. Thus, process reengineering is both process innovation and ecological innovation.

The scope of the process would be minimized, which also presents a change in the process on the first, second and third levels. It would no longer be necessary to perform laboratory analyses and purchase sulphuric acid. Consequently, the use of lime (currently, approximately $1 \mathrm{t}$ is used to process $100 \mathrm{t}$ of crude vegetable oil) and floculant would decrease. This means much less paperwork is required for this kind of task (sample analyses, purchase orders, delivery notes, etc.), fewer workers involved in the process (reduction from 19 to 3 workers) and less time needed to perform the tasks (cut from 16 hours 3 minutes to 3 hours 25 minutes).

The company would collect soapsuds using the existing reservoirs for technical fatty acids and for sulphuric acid. When a suitable amount of soapsuds is collected (25 $t$ is the amount that can be transported in a cistern vehicle), the soapsuds would be transported from the company to the biogas plant. The warehouse worker would, following the order from the line manager of the warehouse, pump the soapsuds into the cistern vehicle, while the line manager of the refinery would handle the dispatch procedure. He prepares the dispatch note and signs it together with the head of the warehouse; the document is then submitted as an accompanying document. One copy is sent to the purchase department for information. The process is completed when the company receives the invoice for the procedure. This change would require additional training for the line manager of the refinery (Verbič and Kern, 2008). The model of the changed process is shown in Figure 4.

\subsection{Organizational and human resources structure after the reengineering and innovation of the process}

Innovation and process reengineering result in changes in the organizational structure, i.e. they decrease the number of organizational units involved in the process (Figure 5). The human resources system is also altered. The systematization of work positions would change, in particular systematization of the position handling the batch soap splitting - the worker would be able to perform other assignments (e.g. the work 
PROCESS REENGINEERING - MODEL (TO BE)

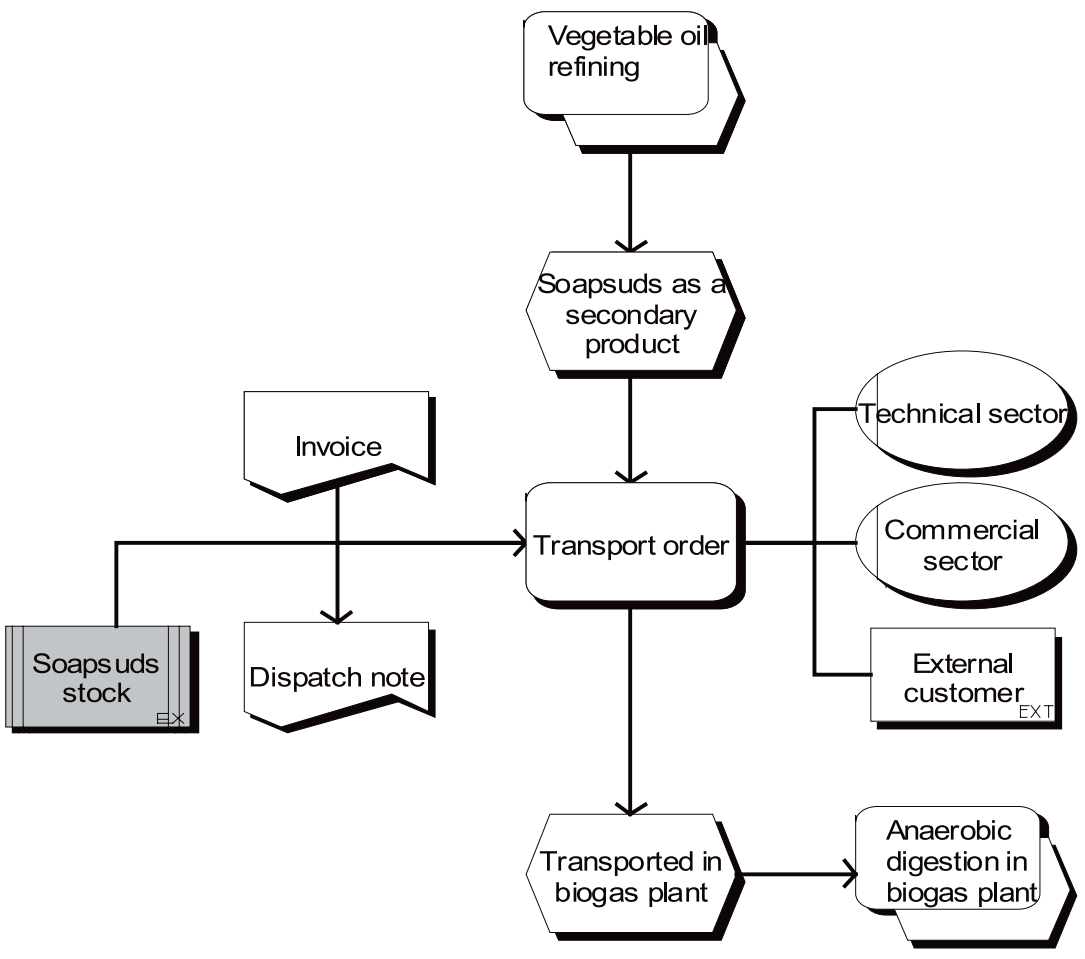

Figure 4: Soapsuds remake after process reengineering - model (Verbič, 2008).

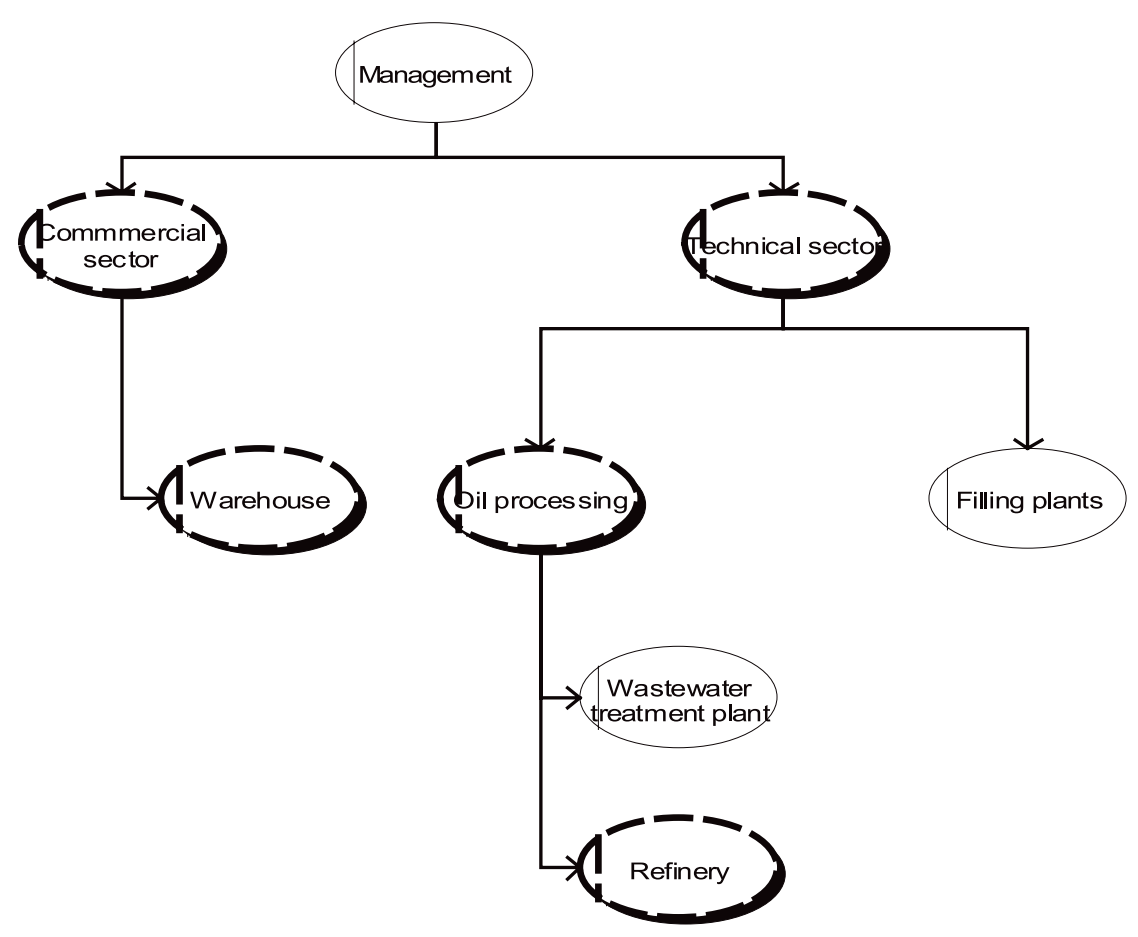

LEGEND:

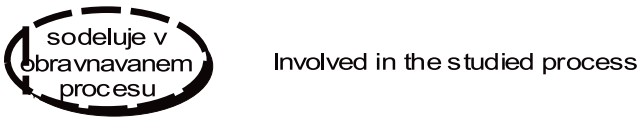

Figure 5:Organizational units involved in the reengineered process - model (Verbič, 2008). 
of a stoker) in half the time. Systematization of work positions for the refinery line manager, purchasing department clerk and workers in the wastewater treatment plant would also change. The proposed changes require modification of the IT system. Therefore, it would be sensible to implement computer-supported measurement of the amount of soapsuds in the reservoirs. The level of soapsuds would be measured by means of an electronic level measuring device. The signal would be connected to the computer. This would enable the refinery line manager to check the amount of soapsuds at any time. This would additionally simplify the process (Verbič and Kern, 2008).

\subsection{Schedule for individual functions after process reengineering and innovation}

The schedule of individual functions after the change is as follows (Verbič and Kern, 2008):
It is clear that the reengineered and inovated process significantly cuts waiting, preparation and finalisation times, but in particular the time spent executing the process itself. Total time spent decreases from the estimated 16 hours 3 minutes to 3 hours 25 minutes.

\section{Estimated results of the anaerobic digestion of soapsuds in the biogas plant}

In order to implement this reengineered and innovated process (which is also innovative in terms of ecological protection) in practice, it is important to know what effect the soapsuds will have on the operation of the biogas plant, as well as how the products resulting from the anaerobic digestion will affect the environment.

Drawing on information from the available literature, we will prove that soapsuds can actually be decomposed in a

Table 2: The schedule after process reengineering and innovation (Verbič, 2008).

\begin{tabular}{|l|l|l|l|l|}
\hline & $\begin{array}{l}\text { AWAITING } \\
\text { EXECUTION }\end{array}$ & $\begin{array}{l}\text { PREPARATION } \\
\text { FOR } \\
\text { EXECUTION }\end{array}$ & EXECUTION & FINALISATION \\
\hline $\begin{array}{l}\text { REPUMPING SOAPSUDS } \\
\text { INTO THE RESERVOIR }\end{array}$ & 5 minutes & 10 minutes & 15 minutes & 10 minutes \\
\hline $\begin{array}{l}\text { SOAPSUDS SALES } \\
\text { PROCEDURE }\end{array}$ & $\begin{array}{l}\text { for the reservoir to } \\
\text { be full }\end{array}$ & 30 minutes & 30 minutes & 10 minutes \\
\hline $\begin{array}{l}\text { PUMPING TFA INTO A } \\
\text { CISTERN VEHICLE FOR } \\
\text { TRANSPORT }\end{array}$ & 10 minutes & 15 minutes & 25 minutes & 15 minutes \\
\hline FINAL SALES PROCEDURE & 5 minutes & 5 minutes & 10 minutes & 10 minutes \\
\hline TOTAL & 20 minutes & 1 hour & $\begin{array}{l}1 \text { hours } 20 \\
\text { minutes }\end{array}$ & 45 minutes \\
\hline
\end{tabular}

biogas plant and that the products (parameters) obtained from decomposition are more acceptable for the environment than products generated by the existing process.

We will describe the effect of the individual substances (parameters) which compose soapsuds on the operation of the biogas plant and, after decomposition, on the environment, both in terms of the pollution of water and soil. The effect will be shown by taking into consideration the concentration of these substances in soapsuds, but without considering the dilution which will most likely occur (depending on the composition of other substrates which are decomposed in the biogas plant). In a larger biogas plant many substrates (up to $250 \mathrm{t} /$ day) are decomposed at the same time, not just soapsuds (Verbič, 2008).

\subsection{Composition of soapsuds}

We determined the composition of soapsuds on the basis of data obtained from the available literature and using calculations based on the data. We took into consideration the addition of sodium hydroxide $\mathrm{NaOH}$ and phosphorus (V) acid $\mathrm{H}_{3} \mathrm{PO}_{4}$ in the crude oil degumming and neutralization phase. Soapsuds as a secondary product of crude vegetable oil processing thus contain (Verbič, 2008):

- in addition to soap, obtained from free fatty acids with added $\mathrm{NaOH}$ and $\mathrm{Na}$ ions, it also contains

- phosphatides, phosphate (added phosphorus (V) acid) to transform non-hydratable into hydratable phosphatides), several other non-defined gums and

- remnants of neutral oil.

Data on the composition of soapsuds, expressed in $\%$ by weight (Rac, 1964):

- unsaponifiable matterss (mostly phosphatides) $0.34 \%$

- neutral oil up to $6 \%$

- soap approximately $13.66 \%$

- water around $80 \%$ (depending how much water is used for washing oil when removing soap).

\subsection{Total content of substances in soapsuds}

When processing $100 \mathrm{t}$ of crude vegetable oil, approximately $7 \mathrm{t}$ of soapsuds are produced (depending how much water is 


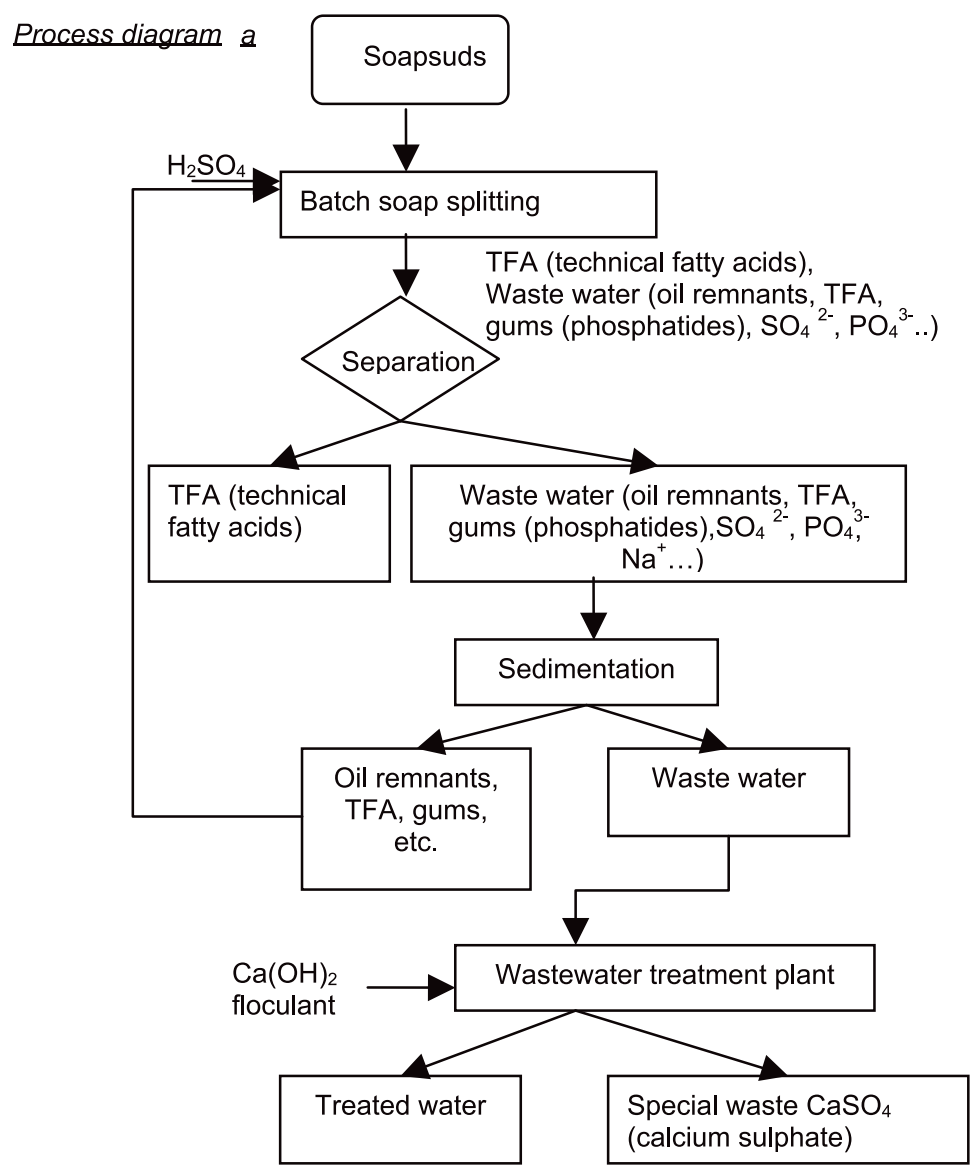

Figure 6:Scheme of batch soap splitting and wastewater treatment (Verbič, 2008).

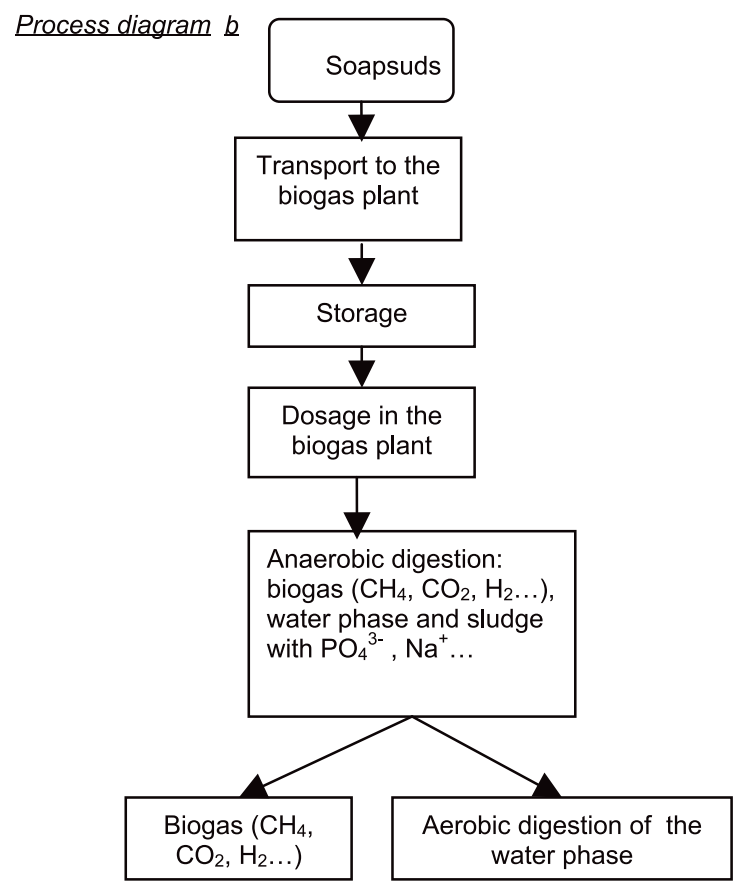

Figure 7:Scheme of anaerobic digestion of soapsuds in the biogas plant (Verbič, 2008). 
used for washing oil) which, according to the calculations, contains (Gunstone et al, 1986, Verbič, 2000, Verbič, 2008):

$\begin{array}{lr}\text { Soap } & 1,000 \mathrm{~kg} \\ \text { Sodium (in soap) } & 81.9 \mathrm{~kg} \\ \text { Neutral oil } & 420 \mathrm{~kg} \\ \text { Phosphatides } & 105 \mathrm{~kg} \\ \text { Phosphorus in phosphatides } & 0.26 \mathrm{~kg} \\ \text { Phosphorus (added } \mathrm{H}_{3} \mathrm{PO}_{4} \text { ) } & 31.6 \mathrm{~kg} \\ \text { Total phosphorus }\left(\text { added } \mathrm{H}_{3} \mathrm{PO}_{4}\right. & \\ \text { and phosphatides) } & 31.9 \mathrm{~kg} \\ \text { Water } & 5443.4 \mathrm{~kg}\end{array}$

\subsection{The biogas plant}

In the biogas plant, decomposition of organic substances takes place under anaerobic conditions and as a result of the action of anaerobic microorganisms, which in an oxygen-free environment - i.e. anaerobic conditions - decompose organic materials into inorganic products $\left(\mathrm{CO}_{2}, \mathrm{H}_{2}, \mathrm{H}_{2} \mathrm{~S}\right.$, and ammonium - $\mathrm{NH}_{3}$ ) and methane $\mathrm{CH}_{4}$.

In the anaerobic process under optimum conditions the proportion of organic substances present can be reduced by $75 \%$. The anaerobic digestion of organic substances can be shown with the following equation:

$\underset{\text { matter }}{\text { Organic }} \stackrel{\text { Anaerobic fermentation }}{\text { bacteria }} \rightarrow \underset{\text { bacteria }+Q}{\mathrm{CH}_{4}+\mathrm{CO}_{2}+\mathrm{H}_{2}+\mathrm{H}_{2} \mathrm{~S}+\text { new }}$

From the equation we can see that, in the absence of oxygen, anaerobic fermentation bacteria decompose organic matter into the gaseous products $\mathrm{CH}_{4}$ and $\mathrm{CO}_{2}, \mathrm{H}_{2}$ and that simultaneously a certain amount of new bacterial mass is produced with an equivalent amount of organic matter. Part of the organic matters is transformed into thermal energy Baras et all, 1979). On the one hand, we obtain biogas, while on the other we get a stable sludge which is easier to store than sludge from aerobic wastewater treatment plants. The resulting wastewater is usually sent in the aerobic wastewater treatment plants.

The anaerobic digestion is always only a part of the entire cleaning procedure ( $75 \%$ reduction of the organic matters), but with a well guided aerobic digestion we can reduce the organic matters by $95 \%$. It is important that with anaerobic digestion high concentrations of organic materials in wastewater do not restrict operation, but for aerobic digestion high concentrations of organic materials in wastewater (BPK5 higher than 2000) are a limitation due to the speed of oxygen transfer from the gaseous to the liquid phase (Baras et al., 1979). The latest practical experience shows that it is possible to reduce the organic matters by up to $90 \%$ with a well guided anaerobic digestion.

The use of the anaerobic digestion is therefore wholly applicable when cleaning industrial sewage with organic matters when one or two of the following conditions are met (Baras et all, 1979) :

- high concentration of organic matter in water,

- high water temperature.

The organic compounds decompose (in wastewater) until $\mathrm{CO}_{2}$ and methane are produced (desired products in the decomposition), as well as certain metabolites following this scheme (Figure 8) (Bischofsberger et al., 2005):

1. In hydrolysis, undissolved compounds are cracked into monomers by exoemnzymes (hydrolaze).

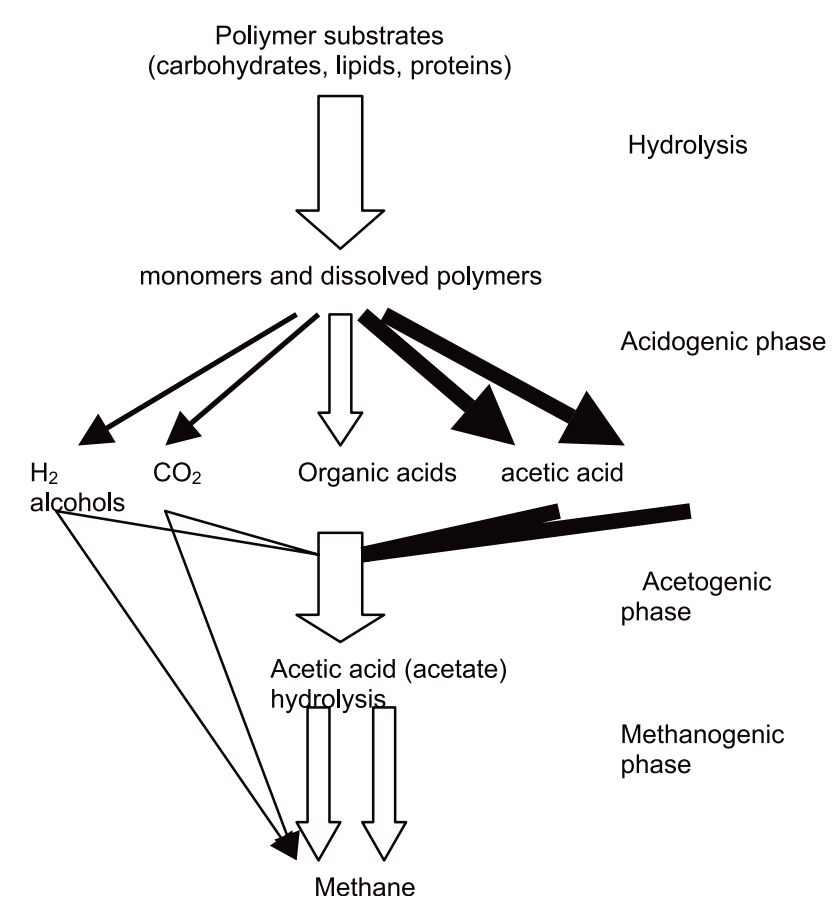

Figure 8:The anaerobic degradation of complex organic compounds (Bischofsberger et al., 2005). 
2. The monomers (monosacharides, amino acids, fatty acids) formed in the hydrolytic phase are taken up by different facultative and obligatory anaerobic bacteria and are degraded in the second, the acidogenic phase, to short chain organic acids. Depending on the environment and the substrate, different products are produced: in the water phase these are mostly lower organic acids (formic, lactic, acetic, propionic and butyric acid) and alcohols (methanol, ethanol); in gaseous phase it is $\mathrm{CO}_{2}$ and $\mathrm{H}_{2}$. The drop in $\mathrm{pH}$ value is typical for the formation of acids due to the production of acids and metabolites with a strong odour (propionic, butyric acid, etc.)

3. Methane bacteria can use only acetic and formic acid, methanol, $\mathrm{CO}_{2}$ and $\mathrm{H}_{2}$ as the substrate. Higher organic acids (propionic, butyric, etc.) are transformed into acetic acid in the so-called acetogenic phase. Due to energy reasons, acetogenic bacteria have to live in a spatially tight symbiosis with methane bacteria (or sulphate reducers). The degradation of propionic or butyric acids into acetic acid can only take place if we constantly remove the product of the reaction - $\mathrm{H}_{2}$, i.e. if we maintain a low partial hydrogen pressure.

4. The methanogenic phase (production of methane) takes place by means of methane bacteria under strictly anaerobic conditions. We can divide them into two types: the first type uses $\mathrm{H}_{2}$, while the second reduces $\mathrm{CO}_{2}$ into methane $\mathrm{CH}_{4}$. Bacteria can gain relatively high levels of energy $\left(135 \mathrm{~kJ} / \mathrm{mol} \mathrm{CH}_{4}\right)$, grow relatively fast and are, in comparison with the second group, $\mathrm{pH}$ tolerant. The second group includes less types of bacteria; they produce methane from acetic acid. The amount of energy obtained in this reaction $\left(31 \mathrm{~kJ} / \mathrm{mol} \mathrm{CH}_{4}\right)$ is substantially lower than with the degradation of the above-listed substrates. Methane bacteria which degrade acetic acid (acetoclastic) are very important, because they produce approximately $2 / 3$ of methane. These bacteria grow slowly, in comparison with the previous type and the constancy of the living conditions is very important. In most cases they determine the efficiency and stability of anaerobic digestion in biogas plants (Stafford et al., 1979).

\subsection{Expected anaerobic digestion of soapsuds in the biogas plant}

Working on the premise that practically all organic matter is decomposed in the biogas plant, and taking into consideration the data from available literature, we conclude that soapsuds will decompose in the biogas plant:

- After hydrolysis and other phases, oils are degraded into light volatile organic acids and further into biogas, which is composed of methane, and small amount of other gases (Figure 8);

- $\quad$ soap and phosphatides are transformed into light volatile organic acids and further into biogas (Figure 8).

In wastewater and sludge (biomass) the following environmentally important parameters remain: sodium or sodium ions, phosphorus or phosphorus ions, temperature and $\mathrm{pH}$.
- Sodium or sodium ions are present as a remnant of the decomposition of soap and as a remnant of sodium hydroxide $\mathrm{NaOH}$ which was added in the crude oil neutralisation phase. The content of sodium per $7 \mathrm{t}$ of soapsuds is $81.9 \mathrm{~kg}$ which means $11.7 \mathrm{mg} / 1000 \mathrm{mg}$. Sodium ( $\mathrm{NaOH}, \mathrm{Na} 2 \mathrm{CO} 3, \mathrm{NaHCO} 3)$ is important as a neutralization agent for balancing $\mathrm{pH}$, because it enables us to solve the problem of precipitation which occurs if we use lime $(\mathrm{CaO}$ or $\mathrm{Ca}(\mathrm{OH}) 2)$ as a neutralization agent as soon as the solubility limit is reached, i.e. the solubility constant of CaCO3 is $4.96 \times 10-9$ (Carbon dioxide...). The discarded calcium carbonate frequently builds up in the anaerobic sludge due to its good sedimentary properties; partially, it leaves the cleaning system as an inorganic suspended load transport at the water outlet. Lime is used because it is cheap. According to Baras (1979) Nat in the amount of $100-200 \mathrm{mg} / \mathrm{l}$ has a stimulatory effect on microorganisms in anaerobic digestion; only in higher concentrations, above $350 \mathrm{mg} / \mathrm{l} \mathrm{Na}$, does it act as an inhibitor.

- Phosphor or phosphorus ions are present as a remnant of the decomposition of phosphatides and as a remnant of phosphoric (V) acid H3PO4 which was added in the crude oil degumming phase. The total content of phosphorus is $31.9 \mathrm{~kg}$ per $7 \mathrm{t}$ of soapsuds, which is $4.6 \mathrm{mg} / 1000 \mathrm{mg}$. To an extent, phosphorus (PO4 3-) is used as a nutrient for bacterial growth (Nekrep, 2004).

- The water temperature is around between $33-40^{\circ} \mathrm{C}$, assuming that we choose anaerobic digestion under the mesophilic operating conditions. According to Zupančič (2005), the anaerobic digestion takes place in three temperature ranges: the psychrophilic digestion at temperatures between $5-25^{\circ} \mathrm{C}$, the mesophilic digestion at temperatures between $33-40^{\circ} \mathrm{C}$, and the thermophilic digestion at temperatures of $50-60^{\circ} \mathrm{C}$. Anaerobic digestion process rate of reactions incresaes at higher temperatures, therefore as regards wastewater treatment technology the mesophilic digestion and and the thermophilic digestion seem the most interesting; the temperatures between $5-25^{\circ} \mathrm{C}$ allows for extremely slow anaerobic digestion. Thermophilic digestion can be up to eight times faster and more efficient than mesophilic digestion. However, the reactors for anaerobic digestion which operate in the thermophile range are considered more unstable and require greater investment of energy, so they are less frequently used (Zupančič et al., 2005). Nekrep (2004) writes that methanogenic microorganisms which determine the speed, efficiency and operation of the biogas plant are adapted to a certain temperature. Even small variations in temperature cause a substantial decrease in activity. Therefore the temperature should be kept exactly within a range of $+/-1-2^{\circ} \mathrm{C}$. Therefore, we can claim that the temperature really will be within the range described.

- As expected, $\mathrm{pH}$ values in the biogas plant is held between 6.6. and 8.0, because, according to Nekrep (2004), pH values out of 6.6. and 8.0 in an alkaline or acidic direction strongly limits the efficiency of the process. Therefore, the metabolism is affected directly and/or indirectly by changing the dissociation level of an entire species of metabolites. The range of stable methane production is 
very narrow. If we want to achieve a stable anaerobic digestion process, we have to maintain this $\mathrm{pH}$ value.

\subsection{Wastewater at the outlet}

The Decree on the emission of substances and heat in the discharge of wastewater into waters and the public sewage system (Official Gazette of the Republic of Slovenia, no. 47/05 and 45/07) in Annex 1 and 2 determines limit parameters which must not be exceeded when discharging wastewater. For the above-mentioned soapsuds we can assume that the wastewater discharged from the biogas plant contains sodium ions and phosphates unless the phosphates are not partially or completely used up as a nutrient for bacterial growth. In terms of reference, the following parameters of permissible concentrations in the discharged water (in our case) were prescribed:
In our case, the sodium and phosphorus content in wastewater are shown as the total sodium and phosphorus content while taking into consideration that sodium and phosphorus remain in wastewater and sludge; phosphorus was not used as a nutrient for bacteria.

Following the assumption that all sodium and phosphorus remain in wastewater, and by taking into consideration the Decree on the emission of substances and heat in the discharge of wastewater into waters and the public sewage system (Official Gazette of the Republic of Slovenia, no. 47/05 and 45/07), wastewater at the outlet of the biogas plant does not contain substances which could have a negative impact on the environment, except for exceeding the maximum concentration limit of phosphorus in wastewater if the latter was to be discharged directly into waters. The above decree does not list the discharge of phosphorus into the public sewage system as a limiting parameter.

Table 3: Permissible concentrations in the discharged water (Verbič, 2008).

\begin{tabular}{|l|c|c|c|}
\hline & & $\begin{array}{l}\text { Maximum } \\
\text { permissible } \\
\text { level of } \\
\text { discharge into } \\
\text { waters }\end{array}$ & $\begin{array}{l}\text { Maximum permissible level of discharge into the } \\
\text { public sewage system }\end{array}$ \\
\hline Parameter & Unit & -- & -- \\
\hline Sodium & & 2 & -- \\
\hline Phosphorus & $\mathrm{mg} / 1$ & 30 & 40 \\
\hline Temperature & ${ }^{\circ} \mathrm{C}$ & $6.5-9.0$ & $6.5-9.5$ \\
\hline $\mathrm{pH}$ & & &
\end{tabular}

Table 4: Concentrations in the discharged water (Verbič, 2008).

\begin{tabular}{|l|l|c|}
\hline Parameter & Unit & Content at outlet \\
\hline Sodium & $\mathrm{mg} / 1000 \mathrm{mg}$ & 14.7 \\
\hline Phosphorus & $\mathrm{mg} / 1000 \mathrm{mg}$ & 4.6 \\
\hline Temperature & ${ }^{\circ} \mathrm{C}$ & $33-40$ \\
\hline $\mathrm{pH}$ & & $6.6-8.0$ \\
\hline
\end{tabular}

Moreover, the decree does not define the maximum allowed concentration of sodium.

The $\mathrm{pH}$ and temperature are within the prescribed limits. An exception would be a possibly higher temperature if, at the biogas plant outlet, wastewater was discharged directly into waters. In practice, the wastewater at the outlet (prior to being discharged into waters or the public sewage system) is usually used to heat the incoming substrate for the biogas plant, which consequently means the wastewater is cooled and savings are made on heating the incoming substrate.

The data presented for sodium and phosphorus ions refer only to the amounts in $7 \mathrm{t}$ of soapsuds (100 t of vegetable oil processed), but do not take into consideration any possible dilution in the biogas plant when, in a bigger biogas plant (1
MW of electrical energy generated per hour), different substrates are processed at the same time (up to $250 \mathrm{t}$ ) each day).

It is important to emphasise that, according to the data in the available literature, wastewater from the biogas plant is, as a rule, sent in the aerobic wastewater treatment plant, because complete wastewater treatment can only be performed in connection with subsequent aerobic digestion (Baras et al., 1979).

\subsection{Sludge (biomass)}

Sludge (biomass), which is also produced in the biogas plant, is essential for the operation of the plant. Only excess sludge is removed. When assessing the effect of sludge removed from 
the biogas plant, our premise is the data regarding the amount of substances in sludge which are produced when $7 \mathrm{t}$ of soapsuds are processed (per $100 \mathrm{t}$ of crude vegetable oil).

The terms of reference for processing biodegradable waste into compost (Official Gazette of the Republic of Slovenia, no. 42/04) state in Article 4 that only biodegradable waste can be composted, as described in Annex 1 to these terms of reference. These substances include waste and sludge from wastewater treatment plants, with the exception of waste and sludge of animal origin and from slaughterhouses. Article 10 states that compost is suitable for use as a plant nutrient if, with regard to the percentage of undesired substances, microbiological requirements and content of hazardous substances, it complies with the requirements of the regulation on emissions into soil.

The decree on the limit input concentration values of hazardous substances and fertilisers in soil (Official Gazette of the Republic of Slovenia, no. 84/2005) in the first item of Article 2 defines emissions into soil or onto the soil as the discharge, dumping or storage of hazardous substances or fertilizers when sludge is emitted from wastewater treatment plants, compost or silt from riverbeds and lakes and when irrigating plants or fertilizing with manure or mineral fertilizers. The fifth item of Article 2 defines as hazardous the substances or groups of substances presented in table 1 of Annex 2 and in table 8 of Annex 3 of the same decree, which are emitted into soil by means of sludge from wastewater treatment plants, compost or silt, or when irrigating plants, and which due to their properties, quantity or density, negatively affect the use of the soil or the quality of the waters. In the sixth item of Article 2 fertilizers are defined as any kind of substances which contain nitrogen compounds or potassium and which, by emission into the soil, encourage the growth of plants. Fertilizers can be of animal or mineral origin, from sludge coming out of wastewater treatment plants, silt, and compost or in the form of fish remnants from fish farms.

In the Annexes of the above decree regarding the annual limit of input of dangerous substances, the maximum value of hazardous substances in sludge, silt or compost are defined. The products resulting from the decomposition of soapsuds, are not included, with exception of the following parameters:
Taking into consideration the terms of reference and regulations, all substances and all products resulting from the decomposition of soapsuds, even in the worst case scenario, will remain in the sludge. The data only refers to the amount of substances in $7 \mathrm{t}$ of soapsuds ( $100 \mathrm{t}$ of processed vegetable oil), without taking into consideration possible dilution when, in a bigger biogas plant (1 MW of electrical energy generated per hour), different substrates are processed at the same time (up to $250 \mathrm{t}$ ) each day. Therefore, we do not expect the sludge to present an environmental burden.

\subsection{Effect of soapsuds on the operation of the biogas plant and the environment}

With regard to the findings and, assuming that organic matters can decompose, we assume that soapsuds should not have a negative impact on the operation of the biogas plant, and that the products (parameters) resulting from decomposition are more acceptable for the environment than products occurring in the process used up to now.

When it comes to the anaerobic degradation of soapsuds in the biogas plant, we ought to mention several other advantages:

- Soapsuds do not contain nitrogen, sulphur or their compounds such as ammonium ions and hydrogen sulphide $\mathrm{H} 2 \mathrm{~S}$. Although in lesser quantities sulphur and nitrogen are important for renewal of the biomass, according to several authors their compounds in certain concentrations, or products resulting from their degradation, may have a toxic effect on microorganisms in the anaerobic digestion process. Balancing their concentration so as to keep them below the toxic limit is difficult (Baras et al., 1979, 1979, Gray, 1992, Nekrep, 2004).

- Furthermore, soapsuds contain no heavy metals such as $\mathrm{Cd}, \mathrm{Cr}, \mathrm{Cu}, \mathrm{Pb}, \mathrm{Ni}, \mathrm{Zn}, \mathrm{As}, \mathrm{Fe}, \mathrm{Mn}, \mathrm{Hg}, \mathrm{Ag}, \mathrm{Al}, \mathrm{Co}$, $\mathrm{Mo}, \mathrm{Se}, \mathrm{Sn}$, which are, in low concentrations, important microelements. The majority of them are necessary for the renewal of the biomass as trace elements; however, they are toxic in higher concentrations (Deublein and Steinhauser, 2008).

- The advantage of the anaerobic digestion of soapsuds in the biogas plant lies also in the fact that soapsuds are composed

Table 5: Annual maximum intake level of hazardous substances and fertilisers in soil (Verbič, 2008).

\begin{tabular}{|l|l|l|}
\hline Parameter & Unit & Annual maximum intake level \\
\hline Sodium (in irrigation water) & $\mathrm{mg} / \mathrm{l}$ & 70 \\
\hline Phosphorus as $\mathrm{P}_{2} \mathrm{O}_{5}$ (livestock manure) & $\mathrm{kg} / \mathrm{ha}$ & 120 \\
\hline
\end{tabular}

of soap (water solution) which makes the hydrolysis phase unnecessary in the biogas plant, except when neutral oil is present. This shortens the degradation period.

- Moreover, soapsuds are composed of soap (esterized free fatty acids) and oils which are more beneficial for the composition of biogas than carbohydrates: Degradation of proteins and fats provides a higher amount of methane. (Eder and Schulz, 2006).

The final answer regarding the effect of soapsuds on the operation of biogas plants and on the pollution of environment can be obtained through practical testing with different incoming substrates in individual biogas plants. 


\subsection{The use of biogas}

With the system for the anaerobic digestion of biodegradable waste we can reverse the trend of slowly accumulating waste materials and the rising cost of their removal. At the same time, we gain heat for heating and/or electrical energy which can be used on location or can be sold to customers (Burns, 2007). The literature also mentions a third option, i.e. gas processing (purification, compriming) and sending biogas to the gas network (due to the fluctuating volume and quality of biogas this would only be possible as an exception).

\section{Conclusion}

The obligatory process of soapsuds remake (soapsuds as a secondary product) is performed in companies which process vegetable oils. This process is necessary due to the requirements of the ecological legislation, as soapsuds are a waste material which is not acceptable for the environment.

The currently applicable obligatory process of soapsuds remake (batch soap splitting) produces technical fatty acids which are sold to the cosmetics industry, as well as wastewater which has to be sent in the aerobic wastewater treatment plant. This process produces another waste material, calcium sulphate, which has to be transported to a special waste landfill site.

The aim of this article was to present how it is possible to create this kind of process, apply it in practice or create it in a manner which proves to be the most beneficial in terms of added value for the business system.

Should this solution be applied, i.e. dispatching soapsuds, this solution would significantly help to cut waiting, preparation and finalisation times, as well as the amount of time taken by the process itself.

This means no more costs for chemicals, lower wages, no more depositing calcium sulphate in special waste landfills, using less electrical energy, less taxes for the environmental pollution and, finally, no more technical equipment for separating soapsuds. The latter is especially important for the new technological vegetable oil processing lines or in plants with old and worn out equipment.

This would result in changes to the organizational structure, the human resources system, systematization of work positions and the information system. It would be sensible to implement computer-managed measurement of the quantities of soapsuds in the reservoirs, which means the line manager of the refinery would be able to monitor the level of supply on a computer screen at any time. This would additionally simplify the process.

It is important to emphasize that innovation and process reengineering contribute towards sustainable development, since environmental care, due to global environmental changes and the ever more stringent ecological legislation, has become one of the ongoing tasks and priorities of the management.

The advantage of anaerobic digestion of soapsuds in the biogas plant lies also in the fact that soapsuds are composed of soap (water solution), which makes the hydrolysis phase unnecessary in the biogas plant, except when neutral oil is present. This shortens the degradation time. With the system for the anaerobic digestion of biodegradable waste we can reverse the trend of slowly accumulating waste materials and increasing costs for their removal. At the same time, we gain heat for heating and/or electrical energy which can be used on location or can be sold to customers.

Based on these findings, we can conclude that it is feasible to decomposed soapsuds in the biogas plant and that the decomposition of soapsuds has no negative impact on the operation of the biogas plant. In compliance with the requirements of the applicable ecological legislation, products (parameters) resulting from this decomposition present less pollution of the environment than the products occurring in the process currently in use.

\section{Literature:}

Baras, J., Brković-Popović, I., Knežić, L., Popović, M. \& Blagojević, N. (1979). Obrada otpadnih voda, II. Deo, Biološka obrada. Beograd: Zavod za grafičku tehniku Tehnološko metalurškog fakulteta.

Bischofsberger, W., Dichtl, N., Rosenwinkel, K.H., Seyfried C.F. \& Böhnke B. (2005). Anaerobtechnik, 2., vollstandig uberarbeitete Auflage. Berlin, Heidelberg: Springer.

Burns R.T. (2007). Animal Waste Anaerobic Digester Basic. Presentation Iowa State University. Retrieved July 27, 2008, from http://www.chpcentermw.org/presentations/041103-IA/ burns.pdf

Carbon dioxide in water equilibrium. Retrieved August 28, 2008, from http://www.thuisexperimenteren.nl/science/carbonaatkinetiek/Carbondioxide\%20in\%20water\%20equilibrium.doc

Deublein, D. \& Steinhauser, A. (2008). Biogas from Waste and Renewable Resources. Weinheim: Wiley VCH Verlag GmbH \& Co. $\mathrm{KGaA}$

Eder, B. \& Schulz, M. (2006). Biogas Praxis. Staufen: Okouch Verlag.

Frankel E. (1990). Management of Technological Change. Dordrecht: Kluver Academic Publishers.

Gray, N.F. (1992). Biology of Wastewater Treatment. Oxford: Trinity College, University of Dublin, Oxford University Press.

Gunstone, D., Harwood, J. \& Padley, F.(1986). The Lipid Handbook. London, New York: Chapman and Hall.

IDS Scheer. (2004). ARIS 6 Collaborative Suite - ARIS Method, Saarbruecken: IDS Scheer AG.

Kern, T. (2008). Organizational structure without hierarchy in a dynamic global business environment. In: Tan F.B. (ed.). Global information technologies: concepts, methodologies, tools, and applications (pp. 2463-2473). Hershey: Information Science Reference.

Kern, T. (2003). Business system repository as a universal business tool. In: Kaluža, J. (ed.). 5th International Conference Strategic Management and its Support by Information Systems, 3-5 September 2003, Horní Bečva. Strategic management and its support by information systems : proceedings : 5th International Conference, 3-5 September 2003, Horní Bečva, Czech Republic (pp. 95-102). Ostrava: Technical University of Ostrava, Faculty of Economics.

Nekrep, F.V. (2004). Anaerobni postopki čiščenja odpadnih vod. Retrieved July 26, 2008, from http://64.233.183.104/search?q =cache:ZdSuWochtoJ:www.bfro.unilj.si/zoo/studij/dodipol/ eko/varokup2001/predavanje_10.htm+anaerobni+metanogen $\mathrm{i}+$ mokroorganizmi\&hl=sl\&ct=clnk\&cd=1\&gl=si 
Rac, M. (1964). Ulja i masti. Beograd: Poslovno udruženje proizvodaća biljnih ulja.

Stafford, D. A., Wheatley, B.I. \& Hughes, D. E. (1979). Anaerobic Digestion (1st International Symposium on Anaerobic Digestion). London: Applied Science Publishers Ltd.

Swern, D., Mattil, F., K., Norris A., F. \& Stirton, J., A. (1964). Bailey's industrial Oil and Fat Products. New York, London, Sydney: Interscience Publishers, a Division of John Wiley \& Sons.

Verbič, A. (2008). Model prenove in inovacija procesa predelave milnice kot stranskega produkta pri predelavi rastlinskih olj. Master thesis, University of Maribor, Faculty of Organizational Science.

Verbič, A. \& Kern, T. (2008). Prenova procesa predelave milnice $\mathrm{v}$ »poslo nem sistemu živilskopredelovalne industrije«. In: Rajkovič, V. et al. (ed). Znanje za trajnostni razvoj (Elektronski vir): zbornik 27. mednarodne znanstvene konference o razvoju organizacijskih znanosti, Slovenija, Portorož, 19.-21. marec $2008=$ Knowledge for sustainable development : proceedings of the 27th International Conference on Organizational Science Development, Slovenia, Portorož, March, 19th-21th, 2008. Kranj: Moderna organizacija.

Verbič, M. (2000). Inovacija v proizvodnji jedilnega olja, Oljarica Kranj, d. d. Diploma assignment, University of Maribor, Faculty of Organizational Science.

Vila, A. (2009). The synthesized organization. Paape, B. (ed.), Vuk, D. (ed.). Synthesized organization (pp. 11-329). Frankfurt am Main (etc.): P. Lang, 2009.

Vuk, D. \& Senegačnik, M. (2003). The role of environmental management. Florjančič, J. (ed.), Paape, B. (ed.). Organisation and management: selected topics (pp. 333-339). Frankfurt am Main (etc.): P. Lang.

Zupančič, G., D., Roš, M., Uranjek Ževart, N. \& Pražnikar, Š. (2005). Ekonomsko smiselna rešitev obdelave blata za čistilno napravo 50000 PE. Retrieved, July 28, 2008, from http://www.sdzvdrustvo.si/si/VD-05_Referatio/Zupancic.pdf

Andreja Verbič has graduated at the Faculty for Chemistry and Chemical technology, University of Ljubljana, Slovenia. She finished the postgraduate study of work process management in 2008 at the Faculty of Organisational Sciences, University of Maribor, Slovenia.

Tomaž Kern is a professor at the University of Maribor, Faculty of Organizational Sciences, and lectures on business processes and project management. He leads a team of experts involved in many research and development projects. His bibliography includes over 300 scientific and technical papers and articles.

Drago Vuk is a professor at the University of Maribor, Faculty of Organizational Sciences. His main research field are environmental aspects of production processes. He is the author of a number of scientific papers which have 12 citations in the journals indexed by the $\mathrm{SCl}$ and $\mathrm{SSCl}$ bases. 